\title{
A nuclear DNA Polymerase in bull spermatozoa
}

\author{
J. M. Richards and S. S. Witkin \\ Laboratory of Cell Biochemistry, Memorial Sloan-Kettering Cancer Center, 1275 York Avenue, \\ New York, New York 10021, U.S.A.
}

\begin{abstract}
Summary. A DNA polymerase was isolated from bull spermatozoa by differential centrifugation, ultrafiltration and gel filtration. Its apparent molecular weight and synthetic template utilization resemble that of DNA polymerase $\gamma$. Chemical and enzymic fractionation of bull spermatozoa indicate that the enzyme is most probably located in the nucleus.
\end{abstract}

\section{Introduction}

Human sperm nuclei contain particulate complexes of high molecular weight RNA and DNA polymerase (Witkin, Korngold \& Bendich, 1975; Witkin \& Bendich, 1977). While in association with the complex, the enzyme can synthesize DNA in the absence of an exogenous template (Witkin et al., 1975; Bendich, Borenfreund, Witkin, Beju \& Higgins, 1976; Witkin \& Bendich, 1977). When the complex is disrupted, DNA polymerase activity can be demonstrated in the presence of synthetic deoxy- or ribo-nucleotide polymers (Witkin et al., 1975; Bendich et al., 1976). In the present study, we have isolated and partly characterized a DNA polymerase from bull sperm heads.

\section{Materials and Methods}

Bull semen was obtained from Dr G. W. Salisbury, University of Illinois College of Agriculture, and stored at $-20^{\circ} \mathrm{C}$ in $50 \%$ glycerol. The semen contained no visible somatic cells or bacteria. Aliquots $(25 \mu \mathrm{l})$ of semen were stained with Giemsa and the degree of contamination was $<400$ organisms $/ \mathrm{ml}$; it was even less after the centrifugation steps. The spermatozoa were pelleted by centrifugation at $1000 \mathrm{~g}$ and resuspended in buffer $(0.05 \mathrm{M}$-Tris- $\mathrm{HCl}, \mathrm{pH} 7.5 ; 0.15 \mathrm{M}-\mathrm{NaCl} ; 1 \mathrm{~mm}-\mathrm{EDTA})$. This procedure was repeated for three cycles to remove seminal fluid contamination. In Exp. 1, the final sperm pellet was resuspended $\left(10^{9}\right.$ spermatozoa $/ \mathrm{ml}$, total vol. $\left.=1 \mathrm{ml}\right)$ in $0.5 \%$ sodium lauroyl sarcosinate (Sarkosyl: Chemical Additives Co., Farmingville, New York), 0.05 M-Tris-HCl, pH 7.5, 10 mm-dithiothreitol (Sigma Chemical Co., St Louis, Missouri), and $75 \mu \mathrm{g}$ trypsin/ml(Worthington Biochemical Co., Freehold, New Jersey). Sarkosyl removes human plasma, acrosomal and nuclear membranes (Witkin, Evenson \& Bendich, 1977) and decaudates other spermatozoa (Millette, Gall \& Edelman, 1974). The addition of dithiothreitol causes the heads to swell because of reduction of the intranuclear disulphide bridges (Bedford \& Calvin, 1974), and then trypsin is able to degrade the chromosomal protein. After incubation at $37^{\circ} \mathrm{C}$ for $15 \mathrm{~min}$, Trasylol (pancreatic trypsin inhibitor: Mobay Chemical Co., New York) was added ( 300 kallekrein inhibitory units $/ \mathrm{ml})$ to inhibit further trypsin action. The resulting viscous solution was treated with $20 \mu \mathrm{g}$ deoxyribonuclease $/ \mathrm{ml}$ (Worthington) and $5 \mathrm{~mm}-\mathrm{MgCl}_{2}$ (final concentration) at $37^{\circ} \mathrm{C}$ for $15 \mathrm{~min}$ to degrade released DNA. Particulate matter, including tail fragments, was then removed by centrifugation for $20 \mathrm{~min}$ at $17000 \mathrm{~g}$. The supernatant was pressure-dialysed in an ultrafiltration cell against a buffer containing $0.05 \mathrm{M}$-Tris-HCl, pH 7.5, 0.02\% Triton X-100, 1 mM-EDTA, $10 \%$ glycerol and 0.5 $\mathrm{M}-\mathrm{KCl}$ (TTK buffer). One-half of the concentrated solution $(300 \mu \mathrm{l})$ was loaded onto a gel-filtration column (Ultrogel AcA-44; 12 000-130 000 molecular weight range: LKB Instruments Inc., Rockville, Maryland), eluted with TTK buffer, and the fractions were assayed (Weissbach, 1975) for $\mathrm{dA}_{\mathrm{n}} \cdot \mathrm{dT}_{12-18}$-templated and $\mathrm{rA}_{\mathrm{n}} \cdot \mathrm{dT}_{12-18}$-templated DNA polymerase activities (see Text-fig. 1 for reaction conditions). Subsequently, a $100 \mu \mathrm{l}$ aliquot of the gel filtration fraction containing 
maximal DNA polymerizing activity was layered onto a $10-30 \%(\mathrm{v} / \mathrm{v})$ glycerol gradient in TTK buffer, centrifuged for $19 \mathrm{~h}$ at $165000 \mathrm{~g}$ and fractionated. The aliquots were assayed for

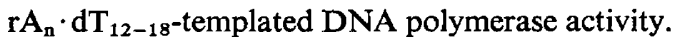

The procedures described for the washing of the spermatozoa reduced seminal fluid contamination of the cells by a factor of approximately $10^{-10}$, but it was possible that any DNA polymerase found was adhering to the sperm membranes or was located in the tail, which contains mitochondria with their associated DNA polymerase (Hecht, 1974). In Exp. 2, therefore, the washed sperm pellet was treated with 1 volume of $0.5 \%$ Sarkosyl, $0.05 \mathrm{M}$-Tris- $\mathrm{HCl}, \mathrm{pH} 7.5$, and $10 \mathrm{mM}$-dithiothreitol and incubated at $37^{\circ} \mathrm{C}$ for $15 \mathrm{~min}$ to solubilize membranes, and remove tails. The swollen sperm heads were then separated from tails and solubilized membranes by centrifugation at $650 \mathrm{~g}$ for $10 \mathrm{~min}$ and resuspended in 10 volumes of Sarkosyl buffer. Differential centrifugation was repeated at $650 \mathrm{~g}$ for $10 \mathrm{~min}$ and the sperm head pellet was resuspended in 1 volume of Sarkosyl buffer. An aliquot removed for examination by phase-contrast microscopy showed that a sperm head population without any tails had been obtained. Trypsin was then added $(75 \mu \mathrm{g} / \mathrm{ml})$ to lyse the sperm heads and the resultant $17000 \mathrm{~g}$ supernatant was pressure-dialysed and subjected to gel filtration and velocity centrifugation as described for Exp. 1.

\section{Results}

\section{Experiment 1}

A large peak of DNA polymerizing activity (Text-fig. 1), able to utilize both synthetic templates but preferring the polyribonucleotide and eluting with a penetration coefficient of approximately zero, was obtained. This elution profile was indicative of a molecular weight of approximately 130000 or greater. Velocity ultracentrifugation of the active fraction from gel filtration revealed a single peak of activity (Text-fig. 2) which possessed a sedimentation rate in the detergent and high salt-containing TTK buffer of approximately $8 \mathrm{~S}$ (calculated by using BSA, $\mathrm{S}=5$, as a marker: Martin \& Ames, 1961).

Template and divalent cation preferences of this 8S DNA polymerase were determined (Table 1). The enzyme preferred $\mathrm{rA}_{\mathrm{n}} \cdot \mathrm{dT}_{12-18}$ as the template-primer, and $\mathrm{Mn}^{2+}$ was the preferred divalent cation, yielding optimal activity at $1 \mathrm{mM}$. $\mathrm{Mg}^{2+}$ was partly able to replace $\mathrm{Mn}^{2+}$ with $\mathrm{rA}_{\mathrm{n}} \cdot \mathrm{dT}_{12-18}$ as the template-primer, but the polymerizing activity was reduced by $50 \%$. Neither $\mathrm{rC}_{\mathrm{n}} \cdot \mathrm{dG}_{12-18}$ nor $\mathrm{rC}_{\mathrm{n}}^{\mathrm{m}} \cdot \mathrm{dG}_{12-18}$ (ribopolymer containing 2'-O-methylcytosine) both of which are reportedly used by viral reverse transcriptase (Gerard, 1975), were utilized by the enzyme.

Table 1. Relative template-primer and divalent cation-dependent activities of the DNA polymerase of bull spermatozoa

\begin{tabular}{rll}
\hline Template-primer & Divalent cation & Relative activity* \\
\hline $\mathrm{rA}_{\mathbf{n}} \cdot \mathrm{dT}_{12-18}$ & $\mathrm{Mn}^{2+}$ & $1 \cdot 0$ \\
$\mathrm{rA}_{\mathbf{n}} \cdot \mathrm{dT}_{12-18}$ & $\mathrm{Mg}^{2+}$ & $0 \cdot 4$ \\
$\mathrm{dA}_{\mathbf{n}} \cdot \mathrm{dT}_{12-18}$ & $\mathrm{Mn}^{2+}$ & $0 \cdot 65$ \\
$\mathrm{dA}_{\mathbf{n}} \cdot \mathrm{dT}_{12-18}$ & $\mathrm{Mg}^{2+}$ & $0 \cdot 1$ \\
$\mathrm{rC}_{\mathrm{n}} \cdot \mathrm{dG}_{12-18}$ & $\mathrm{Mn}^{2+}$ & 0 \\
$\mathrm{rC}_{\mathbf{n}}{ }^{2+} \cdot \mathrm{dG}_{12-18} \dagger$ & $\mathrm{Mn}^{2+}$ & 0 \\
\hline
\end{tabular}

* Relative amount of DNA polymerase activity, assayed as described in Text-fig. 1. The reaction rate was linear for $45 \mathrm{~min} ; 1.0$ corresponds to $120 \mathrm{fmol}$ acid-insoluble product formed per $50 \mu \mathrm{l}$ reaction mixture.

+ This template contains $2^{\prime}-0$-methylcytosine in the ribopolymer.

\section{Experiment 2}

The results of this experiment are not given but patterns similar to those shown in Text-figs 1 and 2 were obtained, indicating that the enzyme was most probably located in the sperm nucleus. 


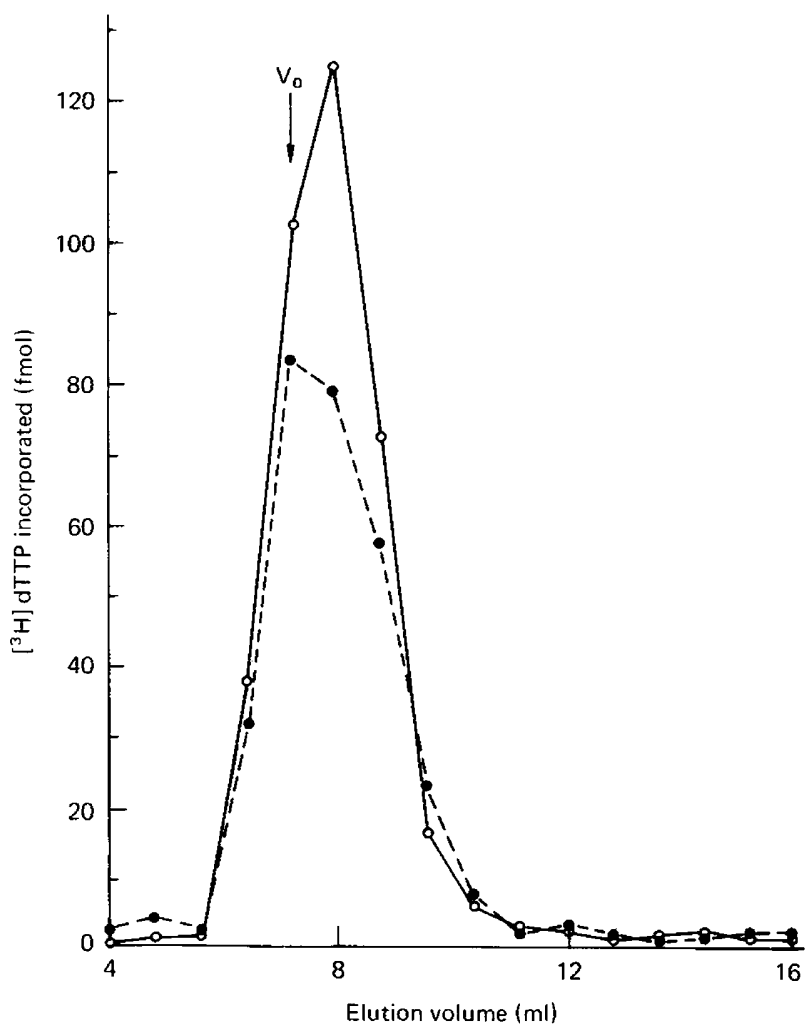

Text-fig. 1. Gel filtration of an extract of bull spermatozoa. A $300 \mu$ l sample of the detergent-solubilized and pressure dialysed bull sperm extract was loaded onto a $60 \times 0.9 \mathrm{~cm}$ gel-filtration column containing Ultrogel AcA-44 in TTK buffer. The sample was eluted with TTK buffer at atmospheric pressure and a flow rate of $4.8 \mathrm{ml} / \mathrm{h}, \mathrm{V}_{\mathrm{T}}=48.6 \mathrm{ml} ; \mathrm{V}_{0}=7.2 \mathrm{ml}$; effective mol. wt range $=12000-130000$. Fractions of $300 \mu \mathrm{l}$ each were collected and $10 \mu \mathrm{l}$ aliquots assayed for $(0) \mathrm{rA}_{\mathrm{n}} \cdot \mathrm{dT}_{12-18}$ or $(\bullet) \mathrm{dA}_{\mathrm{n}} \cdot \mathrm{dT}_{12-18^{-}}$templated DNA polymerizing activities after combination with $40 \mu \mathrm{l}$ of an assay cocktail. The reaction mixture, total volume $50 \mu \mathrm{l}$, contained: $0.32 \mathrm{~mm}-\mathrm{dATP}, 10 \mathrm{~mm}$-dithiothreitol, $1 \mathrm{~mm}-\mathrm{MnCl}_{2}, 0.02 \mathrm{M}-\mathrm{Tris}-\mathrm{HCl}, \mathrm{pH} 7 \cdot 5$, $100 \mu \mathrm{g} \mathrm{BSA} / \mathrm{ml}, 9.6 \mu \mathrm{g}$ template-primer $/ \mathrm{ml}$, and $2 \cdot 17 \mu \mathrm{M}-\left[{ }^{3} \mathrm{H}\right] \mathrm{dTTP}(46 \mathrm{Ci} / \mathrm{mmol}) ; 2 \cdot 17 \mu \mathrm{M}-\left[{ }^{3} \mathrm{H}\right] \mathrm{dGTP}$ ( $6 \mathrm{Ci} / \mathrm{mmol}$ ) were substituted for TTP when $\mathrm{rC}_{n} \cdot \mathrm{dG}_{12-18}$ or $\mathrm{rC}_{\mathrm{n}}{ }^{\mathrm{m}} \cdot \mathrm{dG_{12-18 }}$ were used as templates. Incubation was for $15 \mathrm{~min}$ at $37^{\circ} \mathrm{C}$. The reaction was terminated by addition of $3 \mathrm{ml}$ ice-cold $5 \%$ trichloroacetic acid-1\% sodium pyrophosphate, and the acid-insoluble product was collected on $25 \mathrm{~mm}$ Gelman type A-E filters, dried and counted.

\section{Discussion}

The sedimentation rate of the bull sperm head enzyme corresponds to the sedimentation value for DNA polymerase $\gamma$ from HeLa cells (Spadari \& Weissbach, 1974). The template and divalent cation preferences of the sperm enzyme are also consistent with those described for DNA polymerase $\gamma$ from HeLa cells (Spadari \& Weissbach, 1974) but not for RNA-dependent DNA polymerases (reverse transcriptase) (Wu \& Gallo, 1975) or DNA polymerases $\alpha$ and $\beta$ (Spadari \& Weissbach, 1974).

The function of DNA polymerase $\gamma$ remains uncertain (Weissbach, 1975), Nevertheless, the enzyme is unique in that it is able to copy synthetic ribohomopolymers at a higher rate than deoxyribohomopolymers (Fridlender, Fry, Bolden \& Weissbach, 1972). Its purported inability to transcribe natural RNA in vitro (Bolden, Fry, Muller, Citarella \& Weissbach, 1972) may be an artefact, as suggested by discoveries of ribonuclease-sensitive, endogenous DNA-synthesizing complexes containing DNA polymerase $\gamma$ isolated from the microsomal fraction of rat brain (Witkin \& Schumaker, 1977) and in a nuclear membrane fraction of human lymphoid cells (Yoshida \& Cavalieri, 


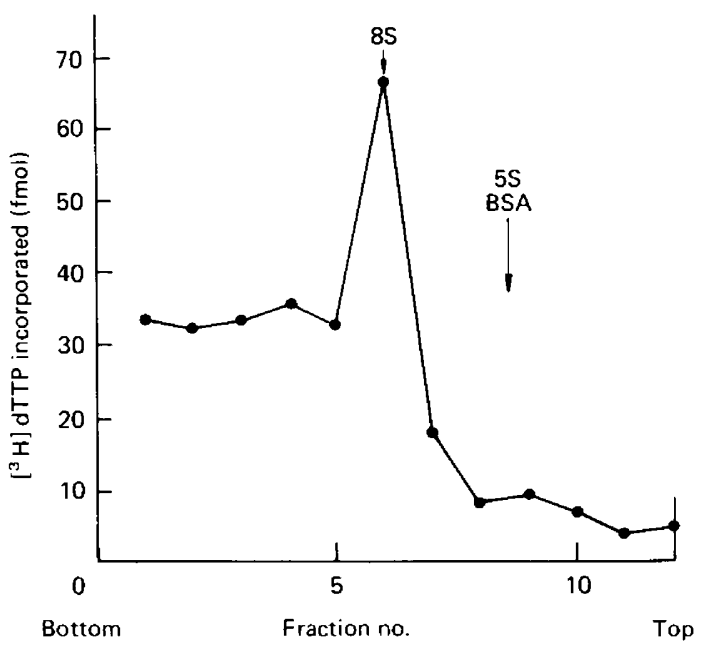

Text-fig. 2. Sedimentation velocity centrifugation of bull sperm DNA polymerase. A $100 \mu$ laliquot of the peak fraction from the gel filtration column (Text-fig. 1) was layered onto a $5 \mathrm{ml} \mathrm{10-30 \% (v/v)} \mathrm{glycerol}$ gradient in TTK buffer. After centrifugation for $18 \mathrm{~h}$ at $165000 \mathrm{~g}, 6-\mathrm{drop}$ fractions were collected from the bottom and $10 \mu \mathrm{l}$ aliquots were assayed for $r A_{n} \cdot d T_{12-18}$-dependent DNA polymerase activity as described in Text-fig. 1 .

1977). The enzyme may thus be capable of DNA synthetic activities not readily expressed in conventional assay systems. In this regard, measurable DNA polymerizing activity was observed only in sperm preparations after they had been subjected to the gel filtration step described here. It appears that the enzyme may be maintained in the sperm nuclei in an inactive form and that gel filtration helps to remove an inhibitor. Another possibility is that inhibitors of the polymerization reaction are also present in the nucleus, even after removal of the acrosome. The latter possibility does not include DNA degrading enzymes because pressure-dialysed preparations did not exhibit any detectable deoxyribonuclease activity (data not shown).

The association of this inactive DNA polymerase with sperm DNA and its conversion to an active form could facilitate the initiation of repair synthesis at appropriate times before DNA condensation or syngamy. In addition, enzyme activation at some specific stage of spermatogenesis or embryogenesis could allow for selective RNA to DNA transcription of specific gene sequences, thus giving rise to selective gene amplification (Witkin et al., 1975). Experiments are now in progress to test these possibilities.

We thank Mr Jeffrey Broadman for excellent technical assistance; Dr Aaron Bendich for his insight and guidance; and Dr G. W. Salisbury for his gift of the bull semen. This work was supported by grants from the Public Health Service (CA-08748), the National Cancer Institute (No. N01-CB-43904) and the National Institute of Child Health and Human Development (No. 1 R01 HD10826-01).

\section{References}

Bedford, J.M. \& Calvin, H.I. (1974) The occurrence and possible functional significance of $-\mathrm{S}-\mathrm{S}$ - crosslinks in sperm heads, with particular reference to eutherian mammals. $J$. exp. Zool. 188, 137-156.

Bendich, A., Borenfreund, E., Witkin, S.S., Beju, D. \& Higgins, P.J. (1976) Information transfer and sperm uptake by mammalian somatic cells. Prog. Nucleic Acid Res. mol. Biol. 17, 43-75.
Bolden, A., Fry, M., Muller, R., Citarella, R. \& Weissbach, A. (1972) The presence of a polyriboadenylic acid-dependent DNA polymerase in eukaryotic cells. Archs Biochem. Biophys. 153, 26-33.

Fridlender, B., Fry, M., Bolden, A. \& WeisSBach, A. (1972) A new synthetic RNA-dependent DNA polymerase from human tissue culture cells. Proc. natn. Acad. Sci. U.S.A. 69, 452-455. 
GrRard, G.F. (1975) Poly (2'-O-methylcytidylate) oligodeoxyguanylate, a template-primer specific for reverse transcriptase. Biochem. Biophys. Res. Commun. 63, 706-711.

Hecht, N.B. (1974) A DNA polymerase isolated from bovine spermatozoa. J. Reprod. Fert. 41, 345-354.

Millette, C.F., Gall, W.E. \& Edelman, G.M. (1974) Differential solubilization of spermatozoa by treatment with Sarkosyl. Fedn Proc. Fedn Am. Socs. exp. Biol. 33, 1395.

MARTIN, R.G. \& AMES, B.N. (1961) A method for determining the sedimentation behaviour of enzymes: application to protein mixtures. $J$. biol. Chem. 236, 1372-1379.

Spadari, S. \& Weissbach, A. (1974) Hela cell Rdeoxyribonucleic acid polymerases. Separation and characterization of two enzymatic activities. J. biol. Chem. 249, 5809-5815.

Weissbach, A. (1975) Vertebrate DNA polymerases. Cell 5, 101-108.

WITKIN S.S. \& BENDICH, A. (1977) DNA synthesizing activity in normal human sperm. Expl Cell Res. 106, 47-54.
Witkin, S.S. \& SChUmakeR, H.M. (1977) A particulate DNA polymerase activity in adult rat brain. Biochem. Biophys. Res. Commun. 75, 568-575.

WrtKIn, S.S., KoRngold, G.C. \& Bendich, A. (1975) Ribonuclease-sensitive DNA-synthesizing complex in human sperm heads and seminal fiuid. Proc. natn. Acad. Sci. U.S.A. 72, 3295-3299.

Witkin, S.S., Evenson, D.P. \& Bendich, A. (1977) Chromatin organization and the existence of a chromatin-associated DNA generating system in human sperm. In Molecular Biology of the Mammalian Genetic Apparatus, Part A, pp. 345-354. Ed. P. O. P. Ts'o. Elsevier/North Holland Biomedical Press, Amsterdam.

Wu, A.M. \& Gallo, R.C. (1975) Reverse transcriptase. CRC Critical Rev. in Biochem. 3, 289-347.

Yoshida, S. \& CAVAlieRI, L.F. (1977) Characterization of a DNA polymerase associated with an endogenous DNA-synthesizing complex isolated from human lymphoid cells. Biochim. biophys. Acta 475, 42-53.

Received 27 September 1977 